\title{
TEKNIK PEMBACAAN DAN MENGHAFAL ŚLOKA, MANTRA VEDA
}

\author{
Oleh : I Made Surada
}

\begin{abstract}
Śloka means stanza, praise or praise, singing and being heard. In the tradition in Bali śloka is the verses of the mantra found in the Vedas. Saying śloka can be said to "follow". Nyruti means listening. The ancient Rsi before knowing reading and writing conveyed the teachings to their students verbally. The students sat cross-legged while listening to the teachings of the teacher. The teacher delivered the teachings in the form of śloka with songs, so it was interesting for the students to listen. This school is usually used in times of accompanying prayers, yajñ ceremonies and for the worship of the people by the Sulinggih. Technically reading the verses of okaloka is with a distinctive rhythm (batten mantra). The language used is Sanskrit. Sound picking is usually at the base of the esophagus so that the sound sounds echoed inward, like the hum of a beetle sucking on flower juice (Bramara angisep sari).
\end{abstract}

Keywords: Reading Technique And Handling, Śloka, and Mantra Veda

\section{Pendahuluan}

Dalam kehidupan masyarakat Hindu di Bali sastra agama tidak terpisahkan. Kebudayaan Hindu di Bali akan dapat dipahami dengan memahami karya-karya sastra baik yang bersifat agama ataupun yang bersifat ilmu pengetahuan (nyastra). Sebagian besar peninggalan karya sastra agama di Bali ditulis dalam lontar. Peninggalan ini merupakan dokumen penting yang memuat acuan kehidupan sesuai dengan norma-norma agama. Disamping itu dalam lontar pula tersimpan berbagai konsep pemikiran leluhur yang dipakai pedoman dan diteladani dalam berperilaku oleh masyarakat pendukung pada zamannya.
Setelah runtuhnya kerajaan Majapait (abad ke-15-16 M) Bali adalah sebagai pelanjut dan tempat bertahta agama Hindu dengan segala aspek budayanya. Sastra Jawa Kuno sebagai sumber ajaran agama Hindu yang berkembang di Indonesia masih tetap terpelihara dan dipelajari di kalangan masyarakat Hindu di Bali. Dokumen sastra lama ini membuat konsep-konsep pemikiran Hindu yang senantiasa dipelajari yang menjiwai kehidupan masyarakatnya. Karya sastra tidak saja dipelajari tetapi dipraktekan di dalam kehidupan seharihari sesuai dengan amanat ajaran agama Hindu yang terkandung di dalamnya. 
Tradisi untuk mempelajari naskah lama ini yang dilakukan secara berkelompok dilingkungan masyarakat Bali yang dikenal dengan mabebasan. Dalam mabebasan karya sastra dibacakan dengan ditembangkan seperti śloka, wirama, palawakya, kidung, termasuk gaguritan atau pupuh. Dalam kegiatan ini para pecinta sastra menterjemahkan, membahas dan mendiskusikan secara mendalam nilai-nilai ajaran yang terkandung di dalam teks-teks karya sastra agama tersebut.

Kegiatan kelompok ini terhimpun dalam satu sekaa (organisasi) yang disebut pesantian. Kegiatan ini dirasa sangat potensial untuk meningkatkan penghayatan dan iman umat Hindu akan ajaran agamanya.

\section{Pembahasan}

\section{1 Śloka}

Ada beberapa pengertian kata sloka, yaitu sloka dalam bahasa Indonesia, bahasa Bali dan bahasa Sanskerta. Sloka ('s' dental) di Indonesia disebut bidal. Bidal adalah jenis puisi lama dalam bentuk peribahasa sastra Melayu lama yang berisi sindiran, peringatan, nasihat, dan sejenisnya. Bidal merupakan jenis peribahasa yang memiliki arti lugas, irama, dan rima serta digolongkan ke dalam jenis puisi, contoh: Bagai kerakap di atas batu, hidup segan mati tak mau. Ada ubi ada talas, ada budi ada balas. Ikan sepat ikan gabus, makin cepat makin bagus.

Sedangkan Sloka dalam kesusastraan Bali adalah mirip dengan sesonggan namun artinya lebih tersembunyi dan memakai kata "buka slokane", contoh buka slokane ajum- ajum puuh sangkure masih ipun. Tetuekipun kadi anak sane seneng belog ajum, pamuputne ipun sane pocol wiadin nemu baya.

Namun Śloka dalam bahasa Sanskerta dalam kamus artinya a stanza, praise, fame (Apte, 2000:342), yaitu bait, pujian atau memujimuji, kemasyuran dan popularitas. Śloka adalah bahasa Sanskerta yang berasal dari kata "śru" artinya mendengarkan, mendengarkan ajaran dari seorang guru (Apte, 2000:341).

Jadi dalam hal ini Śloka adalah bagian ayat atau bait dari kitab suci Veda yang dibaca dengan irama mantra/śruti. Isinya mengandung pujian dan pujaan atas kebesaran Sang Hyang Widhi beserta manifestasinya.

Secara teknis bait-bait śloka dinyanyikan dengan irama (reng) śruti. Mengucapkan śloka dapat dikatakan "nyruti". Nyruti berasal dari kata "śruti" yang berarti ia mendengarkan. Jadi orang-orang Hindu jaman dahulu sebelum tahu membaca dan menulis menyampaikan ajaranajaran pada siswanya secara lisan. Para siswa duduk bersila sambil mendengarkan ajaranajaran dari gurunya (upaniṣad). Gurunya menyampaikan ajaran dalam bentuk śloka dengan tembang, siswanya mendengarkan dengan baik.

Śloka yang dilantunkan oleh para Pinandita dan Pandita atau sulinggih pada saat memimpin suatu upacara yajña disebut dengan mantra. Mantra berasal dari kitab suci Veda yang dipilih sesuai dengan upacara yajña. Demikian juga doa untuk persembahyangan. Bait-bait śloka dinyanyikan dengan irama śruti. Pengambilan suara biasanya di pangkal kerongkongan (bungkahing jihwa atau angkus prana) sehingga suara kedengaran bergema 
ke dalam, seperti dengungan kumbang yang sedang mengisap sari bunga (Bramara angisep sari).

Pembacaan teks śloka dari bait-bait Veda yang oleh pinandita, pandeta/ sulinggih umumnya memakai beberapa cara pengucapan yaitu diucapkan tanpa tembang, palawakya, wirama Sardhula, dan wirama śronca. Kalau jumlah wrêtta atau suku katanya adalah delapan dalam satu baris (sulur) dan empat baris di dalam satu bait, agaknya lebih enak dibaca atau ditembangkan dengan wirama (irama) Sronca (Warjana,1994:84).

Orang merapalkan śloka dengan irama śruti dapat disebut memantra (merafalkan mantra). Reng (irama) mantra adalah Śruti. Kata mantra berasal dari kata man yang berarti pikiran dan tra berarti alat. Jadi kata mantra berarti alat dari pikiran. Apa yang dimaksud dengan alat dari pikiran? Sebenarnya semua kata-kata diucapkan oleh seseorang adalah merupakan alat dari pada pikiran. Kata-kata adalah alat penyambung buah pikiran dari seseorang yang ditujukan pada orang lain atau obyek tertentu. Selanjutnya Mantra adalah kata-kata yang diyakini bukan buatan manusia, tetapi adalah hasil wahyu yang diterima oleh manusia, sebagai alat berkomunikasi khusus dengan Tuhan dan manifestasi-Nya.

Mantra berarti persembahyangan, himne Veda, dan teks suci lainnya. Mantra merupakan susunan kata-kata atau kalimat-kalimat khusus yang mengandung kekuatan ghaib. Dipakai atau diucapkan pada waktu-waktu dan tempat tertentu, dengan tujuan untuk menimbulkan kemampuan tertentu kepada orang yang mengucapkannya atau kepada orang yang membaca mantra tersebut.
Mantra berupa pujian-pujian yang disampaikan dengan kalimat yang halus. Bahasa mantra sangat indah dan berirama, maka mantra adalah termasuk kesusastraan lisan. Mantra dapat digolongkan seni suara karena diucapkan sesuai dengan chanda, yaitu tinggi rendahnya intonasi secara teratur sehingga menimbulkan suara yang harmonis. Pengucapan mantra yang tepat memerlukan latihan, agar intonasi dan tekanan-tekanan suara dapat diucapkan dengan tepat. Mantra yang diucapkan sesuai dengan aturan tersebut dapat menggerakkan kekuatan yang paling dasar dalam diri manusia dan disebutkan pula dapat mengundang segala kekuatan alam yang ada. Cara untuk dapat menguasai suatu mantra, sehingga dinyatakan menjadi orang siddhi mantra (mantra siddhi) adalah dengan melalui latihan dan bimbingan (Pudja,1979).

Mantram yang diucapkan dengan irama yang baik dapat berfungsi sebagai stuti, stava, stotra atau püja yang bermakna untuk mengagungkan kebesaran Sang Hyang Widhi, dengan manifestasi-Nya, dan para leluhur, dan termasuk pula untuk memohon keselamatan, kerahayuan, ketenangan dan kebahagiaan. Dalam fungsinya untuk memohon perlindungan diri, maka mantram berfungsi sebagai Kavaca (baju gaib yang melindungi tubuh dan pikiran kita dari kekuatan-kekuatan negatif atau jahat) dan Panjara (membentengi keluarga dari berbagai halangan atau kejahatan).Oleh karena itu sangat perlu untuk melatih mengucapkan mantra dengan irama yang baik seperti irama śruti. Irama śloka adalah irama mantra itu sendiri.

Untuk lebih memperluas pengetahuan kita tentang śloka-śloka yang ada dalam pustaka 
suci Veda, baik juga kalau diketahui berapa suku kata dalam satu baris yang ditetapkan dalam membentuk śloka seperti : Gayatrī, Anușpup, Bṛhati, Pañkti, Triștup, Jagati dan Ușnaik. Dalam Veda semua itu termasuk dalam Chanda.

Kecuali Gayatrī yang mempunyai tiga baris yang lainnya terdiri dari empat baris dalam pembentukan ślokanya. Dalam setiap baris ada beberapa jumlah suku kata yang berbeda-beda menurut nama śoka tersebut.

1. Śloka Gayatri terdiri atas 3 baris; 8 suku kata dalam setiap barisnya.

2. ŚlokaUșnaik terdiri atas 4 baris; 7 suku kata dalam setiap barisnya.

3. Śloka Anuștubh terdiri atas 4 baris; 8 suku kata dalam setiap barisnya, seperti: Gajagāti, Pramānikā, Vidyumālā, dan Samānikā.

4. Śloka Vṛhatī terdiri atas 4 baris; 9 suku kata dalam setiap barisnya, seperti: Bhujaṅgaśiśubhratāa, Bujangatā, dan Manimadhyam.

5. Śloka Panktih terdiri atas 4 baris; 10 suku kata dalam setiap barisnya, seperti: Tvaritagatiā, Matta, dan Rukmavati.

6. Śloka Triștubh terdiri atas $4 ; 11$ suku kata dalam setiap barisnya, seperti: Indravajra, Upendravajra, Dodhakam, Bramaravilasitam, Rathodhata, Salinī, dan Svāgatā.

7. Śloka Jagatī terdiri atas 4 baris; 12 suku kata dalam setiap barisnya, seperti: Vañśasthavila, Totakam, Pramitākșarà, Bhujaṅgaprayatam, Manimālā, Malati, dan Visvadevī.

\subsection{Bahasa Śloka}

Bahasa yang digunakan dalam Śloka adalah bahasa Sanskerta. Bahasa Sanskerta adalah bahasa yang digunakan dalam Veda. Bahasa Sanskerta dikenal dengan nama Daivīvāk dan hurufnya bernama Devanāgarī. Dalam perkembangan bahasa Sanskerta sesudah di turunkan Veda kemudian para ahli membedakan bahasa Sanskerta ke dalam tiga kelompok, yaitu :

a) Bahasa Sanskrta Veda (Vedic Sanskrit) yakni bahasa yang digunakan dalam Veda yang umumnya jauh lebih tua dibandingkan dengan bahasa sanskerta yang kemudian digunakan berbagai susastra Hindu seperti dalam Hitihasa, Purana, Dharmaśāṣtra dan lain-lain.

b) Bahasa Sanskrta Klasik (Classical Sanskrit) yakni bahasa Sanskerta yang digunakan dalam susastra Hindu seperti Itihasa (Rāmāyana dan Mahābharāta, Purāṇa (Mahāpurāṇa dan Upapurāṇa, Smṛti (kitab-kitab Hukum / Dharmaśāștra).

c) Bahasa Sanskerta Campuran (Hybrida Sanskrit) dan Sanskerta di Indonesia oleh para ahli menyebutkan sebagai Archipelago Sanskrit atau bahasa Sansketa kepulauan yaitu bahasa Sansketa yang digunakan di Indonesia

Dalam kesusastraan Bahasa Sanskerta juga mengenal ilmu persajakan. Komposisi puitis di dalam bahasa Sanskerta adalah ada dalam wujud nadya (prosa), atau padya (puisi) atau komposisi metris seperti śloka. Ilmu persajakan membicarakan menyangkut hukum verivikasi/ versification atau composisi. Sajak/ayat metris Sanskerta diatur oleh kwantitas, bukan oleh aksen. Padya atau bait terdiri dari empat bentuk 
atau baris masing-masing disebut $p \bar{a} d a$ atau perempat. Suatu $p \bar{a} d a$ diatur oleh banyaknya suku kata (aksara) atau oleh banyaknya jumlah silabis (mātrā). Suatu kumpulan suku kata adalah suatu kata seperti dapat diucapkan dengan jelas dengan suara yaitu. huruf hidup, vokal tunggal dengan atau tanpa yang satu atau lebih huruf mati. Mātrā menjadi ukuran memerlukan waktu untuk melafalkan suatu huruf hidup pendek.

\subsection{Guru Laghu Śloka}

Dalam Pingalachanda-śāstra oleh Pingalāchārya dalam śloka Sanskerta mengenal guru dan laghu. Guru-Laghu adalah panjang pendek suku kata dan pola mengenai selang seling huruf hidup pada suku kata terakhir suatu irama Śloka dan Kakawin. Guru-laghu berasal dari kata guru yang berarti berat atau suara panjang dan laghu yang berarti ringan atau suara pendek. Guru lagu merupakan aturan yang penting dalam Śloka dan Kakawin.

Suku kata dinilai guru dalam śloka jika memiliki vokal panjang dan diphthongs seperti: $\bar{a}, \overline{1}, \bar{u}, \bar{r}$, e, ai, āi, o, au, āu dan vocal pendek yang diikuti lebih dari satu konsonan, misalnya: dharma, kar-ma, parārtha, gamya, accha, dan lainlain. Suku kata yang dinilai laghu dalam Śloka adalah yang memiliki semua vocal pendek dan monophthongs seperti: a, i, u, r, dan 1 .

Ketika suatu huruf hidup pendek dan suku kata dengan Anusvāra (m) atau Visarga (h) adalah selalu guru, seperti: kah, kam, kim, tvam, bhvah, svah dan lain-lain. Suku kata yang terakhir suatu $p \bar{a} d a$ adalah dapat dibaca guru atau laghu. Menurut Pandita Gangadasa suku kata pada akhir suatu $p \bar{a} d a$ selalu dianggap guru tidak pernah dihitung sebagai laghu
(सानुस्वारश्च दीर्घश्च वसिर्गी च गुरुर्भवेत्. वर्णः संयोगपूर्वश्च तथा पादान्तगोपवि)

Disamping guru-laghu śloka juga mengenal wṛtta dan mātrā. Wṛtta adalah jumlah suku kata tiap baris dalam bait śloka. Mātrā adalah susunan letak guru laghu masingmasing baris dalam bait śloka, terdiri atas tiga kelompok suku kata, masing-masing disebut dengan Gana atau kaki sillabic. Masing-masing gaṇa bernama: $m a, n a, b h a, y a, j a, r a, s a$ dan $t a$; seperti kutipan berikut ini.

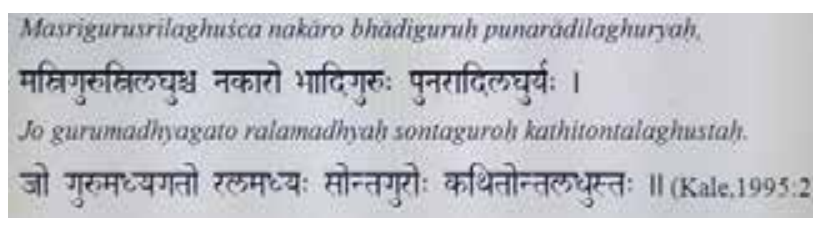

\section{Terjemahannya:}

$\mathrm{Ma}$ adalah semua suku kata panjang; $\mathrm{Na}$ adalah semua suku kata pendek; Bha adalah suku kata pertama panjang dan suku kata kedua dan ketiga pendek; Ya adalah suku kata pertama pendek dan suku kata kedua dan ketiga panjang; $J a$ adalah suku kata pertama dan ketiga pendek, suku kata kedua panjang; $R a$ adalah suku kata pertama dan ketiga panjang, suku kata kedua pendek; $S a$ adalah suku kata pertama dan kedua pendek, suku kata ketiga panjang; $T a$ adalah suku kata pertama dan kedua panjang, suku kata ketiga pendek. Singkatnya seperti tabel berikut ini :

$\mathrm{Ma} / f f f / \quad \mathrm{Ja} /, f, /$
$\mathrm{Na} /,$, / $/ \mathrm{Ra} / f, f /$
$\mathrm{Bha} / f,, / \quad \mathrm{Sa} /,, f /$
$\mathrm{Ya} /, f f / \quad \mathrm{Ta} / f f, /$


Dari perhitungan kelompok tiga-tiga suku kata dalam satu baris śloka, apabila masih tersisa satu suku kata yang terakhir biasa ditandai dengan / /. Suku kata terakhir ini dapat dibaca sebagai guru dan dapat juga sebagai laghu. Kalu sisa terakhirnya dua suku kata, yang pertama guru /- / ini disebut $G a$, yang terakhir laghu /u / disebut $L a$.

Padya atau bait adalah suatu vrtta atau jāti. Vrtta adalah suatu bait adalah mātrā yang diatur oleh posisi dan nomor ;jumlah suku kata pada masing-masing $p \bar{a} d a$ atau perempat bait. Jāti adalah suatu bait mātrā yang diatur oleh banyaknya jumlah tertentu silabis pada setiap $p \bar{a} d a$ atau perempat baris.

Vrtta ada tiga macam yaitu; (1) samavrtta yaitu di mana jumlah suku kata pada masingmasing baris dalam satu pāda sama/serupa; (2) ardhasamavṛtta yaitu di mana jumlah suku kata dalam satu pāda setengah sama yaitu baris pertama sama dengan baris ketiga dan baris kedua sama dengan baris keempat; dan (3) visama vrtta yaitu jumlah suku kata pada setiap baris dalam satu pāda/bait tidak sama.

Ada 26 samavrtta atau metre reguler berlaku umum. Penggolongan ini berdasarkan pada banyaknya suku kata pada setiap baris dalam satu bait, yang mana mulai dari 1 (satu) sampai 26 (duapuluh enam). Masing-Masing kelas ini meliputi berbagai metre semua berbeda dari satu dengan yang lain menurut kombinasi dari berbagai gana.

\subsection{Chanda}

Chanda adalah cabang Veda yang khusus membahas aspek ikatan bahasa yang disebut lagu. Chanda memegang pranan penting dalam sejarah penulisan Veda, karena dengan canda itu semua ayat-ayat Veda dapat dipelihara secara turun temurun seperti nyanyian yang mudah dingat. Dua buah buku Chanda himpunan Bhagavān Pingala adalah Chandasūtra dan Nid̄̄nasūtra.

Chanda adalah metrum atau wirama yang ditentukan oleh aturan jumlah suku kata di dalam sebuah baris atau sebuah mantram Veda. Mantram Veda pada umumnya terdiri dari tiga atau empat baris kalimat dalam satu pāda. Jumlah suku kata yang dihitung adalah suku kata yang konsonannya (vyāñjana) yang mengandung huruf vokal (svara), visarga (h) dan suara sengau (anusvara $\dot{m}$ ). Baris baris mantram Veda ditentukan oleh irama berat ringan, panjang pendek yang disebut dengan guru dan laghu.

Chanda yang terpendek terdiri dari 24 suku kata dan terdiri dari tiga baris. Selanjutnya suku katanya bertambah empat-empat dan barisnyapun berubah menjadi empat baris atau lebih.Yang terpanjang dari kelompok biasa atau sedang terdiri dari 48 suku kata. Yang terpendek dari kelompok yang panjang adalah 52 suku kata dan yang terpanjang terdiri dari 76 suku kata bahkan ada yang 104 suku kata, namun dalam kenyataannya kini kita tidak jumpai lagi chanda yang demikian. Beberapa bentu-bentuk variasi chanda atau metrum dalam mantram Veda adalah sebagai berikut : Gāyatrī, Anuștup (Anuștubh) Bṛhatī (Vṛhatī), Paìkti, Triștup (Triștubh), Jagati, dan Uṣniḥ.

\subsection{Pembacaan Mantram Veda}

Teks Veda ditulis berbentuk prosa, puisiatau prosa liris (Rgveda, Yajurveda dan Sāmaveda). 
Dalam memahami Veda seorang tidak hanya pasih dalam penguasaan tata bahasa (grammar) dan ilmu akar kata (etimologi) tetapi harus memahami aksentuasi. Mantram-mantram Veda mengalir dengan penekannan -penekanan yang indah. Para R̦și tidak hanya gigih memelihara dan mempertahankan mantram-mantram Veda dengan merapalkan dan mengingatnya, tetapi mereka juga mengabadikan cara penekanan ucapan atau aksentuasi dalam pengucapan mantram Veda.

Ada dua jenis pembacaan Veda, yaitu : Padapātha dan Samhitāpātha. Padapātha adalah pembacaan setiap kata pada setiap baris dengan jelas dan terang. Pembacaan dengan di-samdhi-kan (digabung/ditemukan antara kata yang satu dengan yang lain) disebut Samhitāpātha. Samhitāpātha merupakan peluluhan dua atau tiga huruf (svara / vyañjana) yang menimbulkan bunyi yang halus dan setiap kalimat bahasa Sanskerta dapat dianggap merupakan rangkaian dari Samdhi. Pemutusan samdhi kepada bentuk asalnya dianggap akhir dari sebuah kalimat.

\subsection{Aksen Pembacaan Mantra Veda}

Ada empat jenis aksen atau logat tekanan, yaitu : Udātta, Anudātta, Svarita dan Ekaśruti.

1) Udātta adalah tekanan keras, tekanan tinggi atau tekanan tajam. Di dalam Sāmaveda Udātta ditunjukkan dengan angka 1(devanāgarī), contoh : अग्न आ याहि Agna $^{1}$ ā yāhi. Udātta umumnya tidak diisi tanda tekanan, tetapi dapat diketahui melalui dua aturan yaitu : (1) suku kata memiliki tekanan udātta, namun tidak ada tanda tekanan di atasnya, dan demikian pula di depannya. (2) adalah juga udātta bilamana di depannya terdapat Anudātta, contoh : अन्न ये यचम्यवर विन्वतः परिखरसिं । Agne yam yajñama| dhvaram viśvataḥ| paribhūrasi|. (R.gveda I.1.4). Dari contoh di atas menurut hukumnya : (1) 'a' adalah udātta dan (2) yam, ja, dan ra adalah juga udātta.

2) Anudātta adalah tekanan lemah, tekanan rendah, turun. Tekanan ini merupakan tekanan umum, tidak tinggi ataupun rendah. Hal ini ditunjukkan dalam Rgveda, Yajur dan Atharvaveda Samhitā dengan garis datar di bawah suku katanya, seperti contoh : अग्निनां गयिम ग्नवत्पोषमेव दिवे दिवे । Agninā gayima| śnavatpoṣa|meva divedi|ve, (R.gveda I.1.3)

3) Svarita, atau Samahara (disebut oleh Panini) adalah tekanan campuran yang merupakan kombinasi antara tekanan tinggi(udātta) dengan tekanan rendah (anudātta). Svarita di dalam R.gveda ditandai dengan garis kecil tegak lurus di atas suku katanya, contoh : नमों युजानमु namol yujanam. करिष्यसिं karisyasil

4) Ekaśruti adalah monotone atau hanya terdengar satu suara dari ketiga jenis tekanan, oleh karena itu Ekaśruti juga disebut Pracaya. Dalam Ekaśruti ini fungsi Udātta, Anudātta, dan Svarita menjadi tidak jelas dan mejadi satu bunyi saja. Biasanya suku kata yang mengikuti sebuah Svarita dan tidak diberi tekanan (tanda garis tegak kecil) dikenal dengan nama Ekaśruti, contoh: होतांरं रत्नधातंमम् "Hotā|rain "Hotā|raì ratnadhāta|mam" (Rgveda I.1.1) tāa, pada hotāram adalah svarita (diberi tanda berupa garis tegak) dan ram yang mengikutinnya disebut Ekaśruti.

\subsection{Teknik Menghafal Śloka}

Menghafal Śloka diikuti oleh peserta perorangan tingkat anak-anak, remaja dan dewasa putra/putri. Śloka dan terjemahannya dibawakan sendiri dengan cara menghafal. Śloka yang dibawakan sebelumnya diundi dari 30 bait śloka dan dibawakan hanya 10 bait śloka dalam waktu 5 menit. Śloka dibawakan dengan irama śruti periring (irama śruti yang pendek), kemudian diterjemahkan sendiri. 
Śloka adalah menggunakan bahasa Sanskerta. Bahasa Sanskerta adalah bahasa sastra bukan bahasa sehari-hari. Oleh karena itu jika menghafal śloka ada beberapa hal yang perlu diperhatikan, yaitu:

1. Membaca dan cermati kata-kata śloka yang akan difapalkan dengan benar

2. Mengerti dan pahami śloka yang akan difapalkan

3. Mencatat beberapa kata-kata dalam śloka yang sulit dihafal

4. Buat kata kunci dari tiap-tiap bait śloka hafalan supaya gampang diingat.

5. Pengulangan yaitu cara yang paling ampuh dalam menguatkan ingatan. Bila telah hafal dengan baik maka sering-seringlah untuk mengulanginya.

6. Menyanyikan, yaitu dengan cara menyanyikan apa yang akan dihafalkan.

7. Bergeraklah sembari menghafal.Anda akan lebih mudah menghafal sambil bergerak, menggunakan gerakan, menunjukkan emosi sembari menyatakannya. Jangan sekadar mengeluarkan kata-kata, tapi ikuti pula gerakan yang harus anda buat saat sungguh menyampaikannya.

Demikianlah beberapa teknik menghafal śloka terbanyak dalam utsawa Dharmagita.

\section{Kesimpulan}

Śloka adalah nama bait nyanyian pujian dala Veda yang dibentuk terdiri atas beberapa jumlah suku kata dalam satu baris (pāda) dan terdiri dari beberapa baris dalam satu bait (padya). Śloka dinyanyikan dengan irama śruti komposisi suara pada pangkal kerongkongan (bungkahing jihwalangkus prana).
Mengucapkan śloka juga dapat dikatakan "nyruti". Nyruti berarti ia mendengarkan.

Jumlah suku kata dalam satu baris kalimat akan menentukan nama Śloka seperti : Gayatrī, Anuștup, Bṛhati, Pañkti, Triștup, Jagati dan Ușnaik. Dalam Veda semua itu termasuk dalam Chanda. Chanda adalah metrum atau wirama yang ditentukan oleh aturan jumlah suku kata di dalam sebuah baris atau sebuah mantram Veda.

\section{DAFTAR PUSTAKA}

Amulyadhan Mukherji, 1976. Sanskrit Prosody: India: B. Bhattacharjee at Saraswat Press, 206 Bidhan Rasni Calcutta-700006.

Apte, V.G. 2000. The Concise Sanskrit-English

Dictionary. India: Motilal Banarsidass Publishers.

Kale, M.R. 1992. A Higher Sanskrit Grammar (For the Use of school \& College Students). India: Motilal Banarsidass Publishers Private Limited.

Macdonell,A.Arthur, 1997. A Sanskrit Grammar for Students : India. Motilal Banarsidass Publishers Private Limited.

--------, 1999. Vedic Grammar For Students.: India: D.K. Printworld's Edition.

Rani Sadasiva Murty, 1988. Vedic Prosody(Its Nature, Origin and Development). India: Vohra Publishers \& Distributors Allahabad.

Simpen, AB. 1985. Kamus Bahasa Bali. Denpasar: PT Mabhakti.

Surada, I Made. 2006. Dharmagītā (Kidung Panca Yajña, Wirama, Śloka, Palawakya, dan Macepat). Surabaya: Paramita. 
---------, 2007. Kamus Sanskerta-Indonesia.

Surabaya: Paramita.

Tim Penyusun. 1995. Naskah Buku Pedoman

5 Tahun Utsawa Dharmagita. Denpasar:

Proyek Bimbingan dan Penyuluhan

Kehidupan Beragama Tersebar di 9

(sembilan) Daerah Tingkat II di Bali.

Zoetmulder, PJ. 1999. Kamus Jawa Kuna-

Tndonesia [P-Y]. Jakarta : PT Gramedia

Pustaka Utama Jakarta. 